\author{
MARIJA KOCIĆ \\ University of Belgrade, Faculty of Philosophy \\ marijakocich@gmail.com
}

\title{
THE PROBLEM OF "ALBANIAN NATIONALISM" DURING THE REIGN OF KOCA MEHMED RAGIB PASHA (1757-1763) IN THE LIGHT OF THE VENETIAN REPORT ${ }^{1}$
}

\begin{abstract}
This paper examines the position and actions of the Albanian population in certain sanjaks on the basis of published material of Venetian provenance. From the perspective of his position in Constantinople, Francesco Foscari, the Venetian ambassador (1757-1762) in the Ottoman Empire, followed with great interest the developments in connection with the actions of Albanians for several years, especially because their actions threatened to disrupt the Ottoman-Venetian relations. His correspondence is one of the major neo-Ottoman sources regarding the interests of Albanians and their relationship with the Ottoman authorities. This contemporary watched the events from the perspective of a man whose education, beliefs and manners did not belong to the Islamic (Ottoman) cultural sphere, which added credibility to his reports. The reports of Francesco Foscari are kept at the State Archive in Venice (Archivio di Stato di Venezia) and were published in 2007 due to the efforts of the publishing house La Malcontenta and editor Filippo Maria Paladini.
\end{abstract}

Keywords: Albanians, Koca Ragib Pasha, the Ottoman Empire, Venice.

s some historians established, "during the $17^{\text {th }}$ century after the outbreak of any new
war against the Turks there was a rebellion of Albanians." ${ }^{2}$ In addition to similar
Albanianities observed during the Candian War (1645-1669), a great step forward of
1699). This event had consequences not only for the diplomatic position of the Ottoman
state, ${ }^{3}$ but it also caused changes in many institutions, it increased corruption and
dissatisfaction with the authorities, especially among non-Turkish people, ${ }^{4}$ because of long
duration as well as huge expenditure that the Porte had to engage in during the war against

\footnotetext{
${ }^{1}$ The paper is the result of research on project no. 177009 Modernization of the West Balkans financed by the Ministry of Education, Science and Technological Development of the Republic of Serbia.

2 Bartl 2001: 70. Also see: Bartl 1975; Bartl 1976 on these movements.

${ }^{3}$ More details in: Kocić 2014b. It lists additional references.

${ }^{4}$ On the identity of non-Muslim Orthodox subjects of the Sultan during the $18^{\text {th }}$ century on the Balkans see: Kitromilides 1999: 131-145.
} 
the Holy League. For Albanians in the European part of the country and the Kurds on the eastern borders the same conflict enabled a great mobility into the military apparatus. On the other hand, in the later decades this affected more frequent independent attempts of their alienation from formal politics led by the Porte.

Koca Mehmet Ragib Pasha came to the position of the Grand Vizier several months before the death of Osman III (1754-1757). His successor Mustafa III (1757-1774) only confirmed the existing situation. British sources indicate the relationship of a specific nature which was created between the new sultan and Koca Ragib Pasha at the time when he was a prince ${ }^{5}$ held in a cage. ${ }^{6}$ On the other hand, from 1746 to 1768 the Ottoman Empire enjoyed a long period of peace which was utilized in order to settle the internal situation. ${ }^{7}$ As can be expected, the "reforms", as some historians define them, were actually the Porte's effort to improve balance of the state treasury and restore order in all parts of the empire. In this context the tax was a burden not only of the Sultan's subjects, but also of foreign traders who conducted their business in this country. ${ }^{8}$

The events in the Ottoman Empire are significantly evidenced by the sources of French origin, because of the importance that the Porte had for Versailles. An important turning point in the field of the Ottoman-French relations was the Belgrade Treaty in 1739, when France and its representative in Constantinople acted as a mediator taking that role from the British and the Dutch ambassadors. ${ }^{9}$ This, in turn, allowed a greater influence of France on the Porte's foreign policy, while the reports of its ambassadors represent major significant references in the research of many issues related to Ottoman history. The years during which Koca Ragib Pasha enjoyed the position of the Grand Vizier coincided with the Embassy of Graviers Charles, Count de Vergennes (1755-1768). Count de Vergennes, who had been sent to Constantinople as an associate ambassador in 1755, was given the decision of Versailles which renamed him the regular French Ambassador to the Ottoman state. Judging by his biographer, the Porte became a serious factor in the European context, especially in terms of the increased Anglo-French rivalry ${ }^{10}$ and a diplomatic revolution which was in full swing in those years.

Koca Ragib Pasha shared the Sultan's attitude that peace with the great powers was necessary for the development of the country. The measures attributed to him include the improvement of efficiency of the government services. The judiciary was strengthened because of the greater powers given to kadis and because regulations were adopted in order to protect the residents from abuse by provincial officials. ${ }^{11}$ A big failure of his

\footnotetext{
${ }^{5}$ Porter 1768: 112-114 and further.

${ }^{6}$ A separate room in the saray which provided isolation and total alienation from the rest of the world. Keeping Ottoman princes in this rooms dates back to 1595 , when the last mass murder of male successors and pretenders to the throne was committed. See: Imber 2002: 108-109.

${ }^{7}$ Mantran 2002: 319-345, 323. On the events that preceded this and the position of the Ottoman Emprire in the entire European context see: Kocić 2014a: 227-232.

${ }^{8}$ This can be evidenced by the imposition of avaniah, which the Ottoman authorities continued in the later period in order to burden European merchants who did business in the Levant. More details in: Kocić 2014a: 129-134; 232-233.

${ }^{9}$ See this work, which is somewhat pretentiously written in order to emphasize this fact: Laugier 1768

${ }^{10}$ de Mayer $1789: 54-56$.

${ }^{11}$ Mantran 2002: 337.
} 
administration was the fact that taxes were not abolished; instead, special taxes only became regular so the population was overloaded with requests of the central administration. This was also the main cause of many rebellions in almost all parts of the empire. A significant question was whether he influenced the rebellion of part of the Albanian population in the areas of present-day Greece and parts of Macedonia, which are fully evidenced in Venetian sources of the epoch.

Judging by the reports of ambassador Francesco Foscari, Albanians were not a serious problem for the Porte until 1759. As he indicated in his communication, it was a time when efforts in separation from the central government, especially dominant in remote provinces, became apparent to his contemporaries. ${ }^{12}$ Pashas (i.e. sanjak beys) in these provinces acted almost independently of the Porte. These officers enjoyed the title of the pashas with three tails, who had great authority in their hands. At the end of the reign of Mahmud I (17301754) there were 24 of them and by 1759 their number increased to 48 . On the basis of the "barbaric constitution of this empire, the appanage of the great ones"13 exhausted the subjects by the imposition of extraordinary taxes, endangering not only their survival, but also trade in general.

A proof of this statement is the fact that Mehmed Pasha of the Bushatli family was the head of the Shkodra Sanjak since 1757, which was the beginning of a new era in the relations in the region. As some researchers indicated, he was mentioned earlier as a bey of the Bushatli village near Shkodra. Having managed to become the governor of the Shkodra Sanjak, he started solving mutual feuds of influential families trying to end the anarchy in the northern parts of present-day Albania. Because of his attitudes he also managed to gain the support of several Catholic tribes, primarily the Mirditas. ${ }^{14}$

In this redistribution of power for the beylerbey of Rumelia, whose seat was Bitola (the Ottoman Monastir), the Sultan's cousin Mehmed-selektar was elected. However, Mehmed-Pasha decided to stay in Constantinople and he sent a musellim to Bitola "in the capacity of his administrator", who also enjoyed the control over Bursa, Ioannina and Devlin. ${ }^{15}$ At the same time, the Porte was preparing a clash with the Montenegrins, which was entrusted to the Shkodra and Bosnian Sanjak-bey. This was the first important mission of Mehmed pasha Bushatli, who at that time acted only on the orders of Constantinople. According to Francesco Foscari, the priority in the plans of the Porte was the problem of Macedonia, which was raided and robbed by Arnauts, "which means Albanians in Turkish". ${ }^{16}$ This is also their first mention in Foscari's writing since the time he was appointed the Venetian ambassador in Istanbul. Despising Turks, as Foscari interpreted their actions, they invaded Macedonia and dragged the prey that they looted back to Morea and its coastal areas. ${ }^{17}$ Defining its basic channels, the information presented by Foscari revealed the fact that war economy, as the basis of existence of the tribes (not only Albanian tribes)

\footnotetext{
12 Paladini 2007: 151.

${ }^{13}$ Paladini 2007: 152.

${ }^{14}$ Bartl 2001: 73.

${ }^{15}$ Paladini 2007: 198. At the same time tribal anarchy dominated among Montenegrin and mountain tribes. See several documents published in: Milović 1956: 252 and further.

${ }^{16}$ Paladini 2007: 199.

${ }^{17}$ Paladini 2007: 199.
} 
managed to survive. ${ }^{18}$ Members of certain Albanian mountain tribes looted the lowland parts of Macedonia and Epirus, taking goods that were then transported to coastal areas.

The musellim (deputy of Mehmed selektar) and the janissaries under his command tried to oppose them. Albanian marauding squads were shattered not far from Thebes, whereas the people familiar with the situation assumed that they would again attack the next spring. ${ }^{19}$ As Foscari noted, that did not mean that other tribal leaders (he called them capi) ${ }^{20}$ would settle down. Albanians were well supplied with weapons and gunpowder which they made by themselves. ${ }^{21}$ It allowed them to resist all attempts by the authorities to control them. They robbed Salona (a seaport in Aetolia), Stelida in the Gulf of Athens, Larissa with the surrounding territory, and continued to reign terror in Livadia, Thessaly and almost all provinces in Greece. ${ }^{22}$

It was reported in Constantinople that their force had 16,000 soldiers divided into three parts. After each robbery they would retreat to their hiding places in the mountains, which is why they remained inaccessible for the Ottoman army. Because of their method of operation and cruelty of their invasions towards the Sultan's subjects, which turned Macedonia and Greece into unsafe areas, the Porte ordered Sanjak-bey Kyustendil Abdi Pasha to gather all pashas in Rumelia. The plan was to create an army strong enough to be able to control the Albanians. ${ }^{23}$ Janissaries were sent a large sum of money and everything else necessary for the expedition. In mid May 1759 a caravel was sent to Thessaloniki with small field guns and gunpowder. The Venetian consul in Valona, Demetrio Coidan, reported to Foscari that there were 6,000 troops (cavalry and infantry) in the said fort. As the report noted, the news of army grouping came via secret notices which were circulated between the Turks and Arnaut champions. The army gathered in Valona was placed under the command of two sanjak beys and the deputy of the Thessaloniki pasha. ${ }^{24}$

Soon sanjak bey Kyustendil Abdi Pasha was elected the Thessaloniki pasha, which gave him the opportunity to "increase the glory of his name" and help the army in dealing with the Albanians. ${ }^{25}$ The first thing that Abdi Pasha did was to ensure the supply of information about events in the opposing camp. He was helped by a certain Mullah Mustafa, "a murky and talkative man". ${ }^{26}$ The description of Francesco Foscari reveals a man who was able to blab everything he had heard for a good award. Although July was unfolding, the army gathered in Valona did not move anywhere. It was believed that the Albanians would attack villages in Rumelia, which was "largely populated by Turks", while an

\footnotetext{
${ }^{18}$ More details in: Kocić 2013b: 32-35.

${ }^{19}$ Paladini 2007: 199.

${ }^{20} \mathrm{Capi}$ - In the sources of the Venetian provenance this was a usual name for the tribal champion. It was used to signify the princes of Montenegro, the Hills, and Herzegovina since the earliest times and it can be assumed that the same name was used for Albanian and Greek people's champions in other parts of the Ottoman-Venetian border region, especially the mountains.

${ }^{21}$ Paladini 2007: 200.

22 Paladini 2007: 200.

${ }^{23}$ Paladini 2007: 200.

${ }^{24}$ Paladini 2007: 201.

25 Paladini 2007: 216.

${ }^{26}$ Paladini 2007: 216.
} 
additional threat was the plague which ravaged the coastal regions that summer. ${ }^{27}$

The Porte believed that the fact that the Albanians were gathered in their tribal alliances was especially dangerous. Abdi Pasha singled out part of the sipahis and other horsemen led by Abdurahman-aga, who camped near the Arnaut Kazan. Mullah Mustafa and his followers defected here. In Larissa a certain Greek Bucovala "cooper by trade," brought together 700 "thieves" and banished all the murderers from this territory and ensured peace in the city. The most important concern of Francesco Grimani, the Venetian general governor of the sea (Provveditore General do Mar) ${ }^{28}$ was to provide a safe border, while Xiromero (a Venetian estate) was attacked by the Sultan's subjects.

The Porte sent to Ismail Pasha in Valona a firman ${ }^{29}$ which ordered him to destroy these criminals, while the ambassador's only option was to put pressure on the Porte via the interpreter in order to spare the Venetian possessions in Greece. ${ }^{30}$ Abdi Pasha stayed in Valona during most of the summer and in early fall. ${ }^{31}$ As the year 1759 drew to a close, Albanians started moving again. In the fall they attacked the town of Zagora, plundering a caravan carrying silk, cloth and other goods. ${ }^{32}$ Albanians carried out the second attack in Pagasitikos Gulf, where they were not only satisfied with robbery, but also captured many slaves. This second attack, for which Foscari said occurred on 18 October, resulted in the burning of the city. On that occasion 5,000 houses and shops were destroyed, ${ }^{33}$ not only of the Sultan's subjects, but also of Europeans who developed business in that city. ${ }^{34}$

In the first days of January 1760 the interpreter of the Venetian ambassador was invited at the Reis Effendi, ${ }^{35}$ as specified in the message, "after four years of silence." 36 The Venetian side was accused of the raids on the territory of the Sanjak of Shkodra previously committed by the residents of Brzeća and Stoliv. Also, the Venetians were accused of stirring up the local population in the sanjaks of Shkodra, Bar and Ulcinj. The report specifically alluded to the case from 1756, when 200 Catholics from this sanjak fled from

\footnotetext{
${ }^{27}$ Paladini 2007: 216.

${ }^{28}$ In the administrative structure of the Venetial Republic the General Governor of the Sea, i.e. of all naval forces of Venice at a certain moment. This Provveditore was at the head fo a special Magistrate and had authority for naval activities, not just during the war, but in peaceful times. His duties included the control of all forms of smuggling as well as the defence of naval space of the Venetian Republic. The most significant Venetian stronghold in the defensive system of Venice which the Provveditore was ties to was Corfu. However, as time went by, this function became more susceptible to public criticism, not just because of a number of incompetent people who did this job, but also because of their negligence. More details in: Casini 2001: 219-270.

${ }^{29}$ Firman (Tur. firman, Per. farmân) - represents a legislative act which bore the Sultan's personal mark.

${ }^{30}$ Paladini 2007: 323.

${ }^{31}$ Paladini 2007: 255.

32 Paladini 2007: 261-262.

${ }^{33}$ Shop (Per. dükkan) - a workshop where a craftsman, a member of a certain guild, make his products and sold them to customers. The shops were an inseparable part of every bazaar of every Ottoman town. More details in Kocić 2010: 80-84.

${ }^{34}$ Paladini 2007: 262.

${ }^{35}$ Reis effendi (Tur. reis efendi), also reis-ül küttab (Ttur. reis-ül küttab) - the main secretary (scribe) of the state office in the saray. As time went by, especially since the end of the $17^{\text {th }}$ century, this position increasingly gained importance in the state politics, especially in relations with other states.

${ }^{36}$ Paladini 2007: 277.
} 
Bar to Ancona on a ship sailing under the Venetian flag. ${ }^{37}$ The same event was mentioned by Peter Bartl, stating that these defectors then inhabited the papal state. ${ }^{38}$ However, the very fact that they were transported by a Venetian boat put Venice in a difficult position, threatening to open a new crisis in its relations with the Porte.

"The Albanians' resistance" continued as time went on. The pashas of Valona and Thessaloniki, outside of the control of Constantinople, led their policies not understanding the real reason behind the Albanian population's revolt. The confusion that dominated in those areas, which Francesco Grimani, general governor of the sea, reported to Foscari, culminated and then the Porte removed their administrators. Ahmed Aga was appointed in Delvin and Valona, and Ioannina also got a new administrator. ${ }^{39}$ The main cause of such a situation in these areas, as Foscari said, were corruption and despotic rule in the way they were managed. ${ }^{40}$

In the area of Albania, as Foscari stated, without any intention to further define the borders of the territory, riots were resumed. The territory of Greece all the way to Lepanto was restless. The Porte had previously appointed Ismail Pasha, a pasha with three tails, as the warden in Ioannina, and Ibrahim Pasha in Kavala. However, they made ties with the local population and turned them against the Porte. In such an setting Albanian leaders continued to loot the Turks and Greeks in these areas. ${ }^{41}$ Ismail Pasha was a powerful man who enjoyed great prestige, especially among Albanians. He tried to form a large army with which he could resist the attacks of the Albanians. For more effective defense he built a fort (palanka) ${ }^{42}$ which he supplied with arms and ammunition from the neighboring fortresses. Ibrahim Pasha, whose administrative center was in Kavala, sent janissaries in defense of Durres. As Foscari stated, 4,000 Albanians threatened that town on that occasion. The basic aim of these measures was for the Albanian people to return under the wing of the Porte. The beylerbey of Rumelia was required to go after the rebellious Albanians as soon as possible. For that reason the armies of Shkodra, Valona, Ohrid and Devlin united and were joined by the captains of Spuž and Bar. ${ }^{43}$

The beylerbey of Rumelia continued to work against Ismail Pasha, who he represented as a rebel. The current Pasha of Ioannina, bolstered by the support he enjoyed among the population, also harbored irreconcilable hatred towards Ismail Pasha. He offered to the beylerbey to send troops. Although Ismail Pasha was described as a man of great courage who did not lack either money or supporters, he decided to escape on one of the ships from Ulcinj accompanied by a few followers. ${ }^{44}$ Francesco Foscari assumed that his escape would affect other Albanian commanders to settle down. Ismail Pasha landed at the mouth of the

\footnotetext{
${ }^{37}$ Paladini 2007: 278-279.

${ }^{38}$ Bartl 2001: 63.

${ }^{39}$ Paladini 2007: 291.

${ }^{40}$ Paladini 2007: 291.

${ }^{41}$ Paladini 2007: 324.

${ }^{42}$ In this period, a palanka was a wooden fort most often built at an important location or in order to defend border areas such as Hungary, Herzegovina, parts of Bosnia, Dalmatia towards Venice, although in all these regions part of the function of a palanka was performed by a tower. More on a palanka as a category of settlement in the Ottoman society in: Kocić 2010: 32.

${ }^{43}$ Paladini 2007: 325.

${ }^{44}$ Paladini 2007: 337-338.
} 
Bojana, from where he planned to escape to Ulcinj or another place. ${ }^{45}$ In the area of Larissa (Thessaly) and the neighboring areas of Macedonia, as was said among the diplomats in Istanbul, obedience and respect for authority completely disappeared. ${ }^{46}$

There was no mention of Ismail Pasha for a long time in the reports of Francesco Foscari. The news of Ismail Pasha was heard on 17 October 1761. In the report on that date Foscari stated that Ismail Pasha had previously enjoyed a position of the Shkodra Pasha. In the meantime he was pardoned by the Porte, who decided to entrust him with the management of Devlin and Valona. ${ }^{47}$ The rehabilitation of Ismail Pasha was obviously not an accident. As Foscari described the situation in Constantinople in the entire Ottoman Empire, Koca Ragib Pasha sparked the anger of the residents, who used every opportunity to rebel. Several fires that broke out during the previous nights in Istanbul were connected with the dissatisfaction that occurred in relation to the politics pursued by Koca Ragib Pasha. Mosques became the centers of agitation ${ }^{48}$ and from there the discontent against the grand vizier spread among the people. ${ }^{49}$ This explains the compromise that was sought to rehabilitate Ismail Pasha.

Even after Ismail Pasha took power in Devlin and Valona, Albanian tribes were not completely settled. Those who were more cautious in their attitudes could not have expected a different outcome because, in addition to animal husbandry, a great number of them opted for war economy, in which the robbery was a legitimate means for obtaining the material goods as the source of its prosperity. The channels used for centuries were used for looted goods to reach the coast, where it was sold to Italian merchants or tradesmen from different parts of Dalmatia. However, the growing influence of some European countries, particularly France, regarding the events in the hitherto Venetian sphere of interest, influenced the changing constellation of relations in this part of the Venetian-Ottoman border. ${ }^{50}$ In the process they were relying on some Albanian families whose way of life described here raised them to the top of the tribal and administrative hierarchy. This was especially true when a vacuum was created after the fall of the Venetian Republic in 1797. This very development of events announced the rise of Ali Pasha Janjina ${ }^{51}$ and other Albanian leaders, who again drew Albanians into big European events, after long periods of absence. ${ }^{52}$

$* * *$

In the middle of the $18^{\text {th }}$ century the Albanian ethnic group, having learned from the

\footnotetext{
45 Paladini 2007: 353.

46 Paladini 2007: 354.

${ }^{47}$ Paladini 2007: 525.

${ }^{48}$ Although it is not said which mosques, it can be guessed that these are the Sultan's mosques. They were built by local rulers in the Sultan's name and were financed in a different way from the mosques built in other waqfs. More on these mosques in: Kocić 2010: 48-55. Because of their significance and position in the life of the town they became the places where there were increasingly more frequent voices against the current authority, which was especially true since the end of the $17^{\text {th }}$ century. More in: Kocić 2012: 442-449.

49 Paladini 2007: 524.

${ }^{50}$ See: Dajč 2015: 160-220. It lists additional references.

${ }^{51}$ More details in: Skiotis 1971: 219-244; Kocić 2013a: 205-221.

${ }^{52}$ On the existence of the dimension of tolerance in these events during the $19^{\text {th }}$ century see: Gawrych 1983: 519 536.
} 
previous development, started taking more seriously the events in some Ottoman provinces, which was reflected on the relations between the Porte and Venice. This fact was of crucial importance in an attempt to use the Venetian sources in order to acquire insight into the functioning of certain Albanian tribes. Due to the negligent attitude towards history, which is why many events linked to the Albanian ethnic group are still the subject of sometimes hasty speculation, historians are forced to use this kind of source during the reconstruction of real events. An attempt of the rebellion against the Porte was closely related to tribal anarchy which disintegrated the Albanian ethnic group into semi-independent tribes who turned to robbery and feuding as the basic criterion in settling justice defined in their own understanding. Such a development in the late $18^{\text {th }}$ century influenced some European countries on the fringes of the Ionian Sea, which tied themselves to the interests of some Albanian lords, to create bases for the realization of their own ambitions towards the Ottoman Empire.

\section{REFERENCES:}

Bartl, P. Albanci, Beograd: Clio, 2001. [Бартл, П. Албаничи. Београд: Clio, 2001.] . Quellen und Materialien zur geschichte im 17. und 18. Jahrhundert. Band I Albanishe Forschungen, bd. 15. Wiesbanden: Harassowitz, 1975. . Quellen und Materialien zur geschichte im 17. und 18. Jahrhundert. Band I Albanishe Forschungen, bd. 20. Wiesbanden: Harassowitz, 1976.

Casini, M. 'Immagini dei capitani generali „da Mar“ a Venezia in età barocca' in: Marcello Fantoni (ed.), Il "Perfetto Capitano". Immagini e realtà (secoli XV-XVII), Roma: Bulzoni, 2001, 219270.

Gawrych, G. W. „Tolerant Dimensions of Cultural Pluralism in the Ottoman Empire: The Albanian Community, 1800-1912“, International Journal of Middle East Studies, 15, n 4, 1983, 519536.

Dajč, H. E., Jonska ostrva 1774-1815, Beograd: Filozofski fakultet, 2015. (doktorska disertacija).

de Mayer, Ch. J., Vie publique et privée de Charles Graviers, comte de Vergennes, Ministre d'Etat; Discours Couronné par l'Académie d'Amiens, le 25 Aout 1788, Paris: Chez Maradan 1789.

Imber, C. The Ottoman Empire, 1300-1650. Basingstoke: Palgrave MacMillan, 2002.

Kitromilides, P. M. 'Ortodox Culture and Collective Identity in the Ottoman Balkans during the Eighteenth Century', Oriente Moderno, n. s. 18, n 1, 1999, [The Ottoman Empire in the Eighteenth Century], 131-145.

Kocić, M. „Ali Paša Janjinski u spisima Karla Aurelija Vidmana (1794-1797)“, Istraživanja, 24, 2013a, 205-221. [Коцић, М. „Али-паша Јањински у списима Карла Аурелија Видмана (1794-1797)“, Истражсиваға, 24, 2013а, 205-221.]

. Venecija i hajduci u doba Morejskog rata, Beograd: Hesperiaedu \& Naučno društvo za istoriju zdravtvene kulture, 2013b. [Коцић, М. Венеција и хајдуци у доба Морејског рата, Београд: Неsperiaedu \& Научно друштво за историју здравствене културе, 2013b.]

. Diplomatija u službi kapitala: evropske nacije na osmanskom Levantu (XVI-XVIII vek). Beograd: Hesperiaedu, 2014a.

Orijentalizacija materijalne kulture na Balkanu: Osmanski period XV-XIX vek. Beograd: Hesperiaedu \& Filozofski fakultet, 2010. [Коцић, М. Оријентализација материјалне културе на Балкану. Османски период $X V-X I X$ век. Београд: Неsperiaedu \& Филозофски факултет, 2010.] 
. 'Sultan Mosques: Religion and Ideology as seen by Ottoman Architecture', in: M. Vladimir, M. Roter and M. Vukotić (eds.), International Conference "Architecture \& Ideology”, Belgrade: Faculty of Architecture, 2012, 442-449.

Turska u međunarodnim odnosima 1688-1699: put u evropsku diplomatiju. Beograd: Hesperiaedu, 2014b.

Laugier, M.-A. Histoire des Négociations pour la Paix Conclude a Belgrade Le 18 September 1739. Entre l'Empereur, la Russe \& la Porte Ottomane, a la mèdiation \& sus la garantie de la France, vol. I-II, Paris: Chez la Veuve Douchesne, rue Saint-Jacques, au Temple du Gout, 1768.

Mantran, R. „Osmanska država u XVIII veku: evropski pritisak“, u: Rober Mantran (ur.) Istorija Osmanskog carstva, Beograd: Clio, 2002, 319-345. [Мантран, Р. „Османска држава у XVIII веку: европски притисак”, у: Робер Мантран (ур.) Историја Османског ичарства. Београд: Clio, 2002, 319-345.]

Milović, J. M. Zbornik dokumenata iz istorije Crne Gore (1685-1782), Cetinje: Istorijski institute NR Crne Gore, 1956. [Миловић, J. М. Зборник докумената из историје Црне Горе (16851782), Цетиње: Историски институт НР Црне Горе, 1956.]

Paladini, F. M. Francesco Foscari Dispacci da Constantinopoli 1757-1762, Venezia: La Malcontenta, 2007.

Porter, J. Observations on the Religion, Law, Government, and Manners of the Turks, vol. I-II. London: Printed for J. Nourse, Bookseller to His Mayesti, 1768.

Skiotis, D. N., 'From Bandit to Pasha: First Steps in the Rise to Power of Ali of Tepelen, 1750-1784', International Journal of Middle East Studies, 2, n 3, 1971, 219-244.

МАРИЈА КОЦИТ

Универзитет у Београду, Филозофски факултет

\section{ПРОБЛЕМ „АЛБАНСКОГ НАЦИОНАЛИЗМА“ \\ У ВРЕМЕ КОЏА МЕХМЕД РАГИБ-ПАШЕ (1757-1763) У СВЕТЛУ МЛЕТАЧКИХ ИЗВЕШТАЈА}

\section{Резиме}

Средином осамнаестог века, због одређених догађаја који су се десили, албански етникум је добио истакнутију улогу у османским провинцијама, што је утицали на односе између Порте и Венеције. Овај обрт догађаја чини значајним покушаје да се стекне бољи увид у активности одређених албанских племена, а на основу млетачких извора. Неодговоран однос према историји је довео до тога да се многи догађаји везани за албански етникум тумаче са много нагађања, па су историчари принуђени да користе ову врсту извора да би реконструисали праве догађаје. Покушај побуне против Порте је уско везан за племенску анархију која је распршила албански етникум у полунезависна племена склона пљачкању, са крвном осветом схваћеном као главним начином постизања правде. Овај низ догађаја довео је до тога са су неке европске државе на ободима Јонског мора пронашле заједнички интерес са истакнутим Албанцима и формирале упоришта да би оствариле своје амбиције према Османском царству.

Кључне речи: Албанци, Коџа Рагиб-паша, Османско царство, Венеција. 